\title{
Tainted Food, Low-Quality Products and Trade*
}

\author{
Jean Marie Viaene ${ }^{\dagger}$ \\ Erasmus University Rotterdam, \\ Tinbergen Institute and CESifo
}

\author{
Laixun Zhao $^{\dagger+}$ \\ Research Institute of Econ \& Business \\ Kobe University
}

Preliminary draft: August 11, 2009

Please do not cite or quote without permission

\begin{abstract}
This paper examines international trade in tainted food and other low-quality products. We first find that for a large class of environments, free trade is the trading system that provides the highest incentives for foreign exporters to produce non-tainted high-quality goods. However, free trade is neither a necessary nor a sufficient condition to exclude trade in tainted products. This condition is less easily satisfied if the marginal cost of high-quality production increases, or if Type I and Type II errors of testing product quality matter. We also examine cases of image-building investments and sabotage. In particular, sabotage by the domestic firm reduces the foreign firm's incentives to produce high quality, and as a consequence tends to increase import tainting.
\end{abstract}

JEL Classification Number: D43, F12, F13, I12

Keywords: asymmetric information, experience good, product differentiation, sabotage, tainting, trade.

\footnotetext{
*We thank Rick Bond, Fumio Dei, Jota Ishikawa, Ron Jones, Lutz Kilian, Larry Qiu, and seminar participants at Kobe for helpful comments and suggestions. Part of the paper was written while J.-M. Viaene was visiting the Research Institute of Economics and Business of Kobe University, whose hospitality and financial support are gratefully acknowledged.

\section{Addresses for Correspondence:}

${ }^{\dagger}$ Department of Economics, H8-8, Erasmus School of Economics, Erasmus University, P.O. Box 1738, 3000 DR Rotterdam, The Netherlands; E-mail: viaene@few.eur.nl; Fax: +31-10-4089161; Phone: +31-10-4081397.

${ }^{\dagger \dagger}$ Research Institute of Economics \& Business, Kobe University, Kobe 657-8501, Japan; E-mail: zhao@rieb.kobe-u.ac.jp; Fax/Tel: +81-78-803-7006.
} 


\section{Introduction}

Media around the world abound with examples of malpractices in the daily running of international trade. In particular, headlines have alarmed consumers on the safety issues of imported products. Recently, it was revealed that some unscrupulous companies in China had routinely added melamine to milk to artificially boost protein readings in quality tests. Though imports from China have drawn the most criticism, ${ }^{1}$ producers in other developing nations violate basic food safety standards as well (Mexican cantaloupe, Indian relishes, etc.). Furthermore, firms of developed countries have also been known for committing the alleged crime of using dangerous ingredients. For example, Morinaga Milk Industry of Japan added industrial arsenic to improve the solubility of dairy products around 1953; aniline was added to rapeseed oil in Spain in 1981; and most recently, it was found that Peanut Corp. America continued to sell their tainted peanuts and pastes for more than a year, even after the company knew the products tested positive for salmonella. As more goods from distant locations are traded internationally, the question of what determines the deviant behavior of enterprises assumes increasing relevance.

An important factor affecting firms' behavior is consumers' preference for domestically made products over imported goods, especially when it comes to buying food. Consumers in richer countries discount goods made abroad, more so those coming from developing countries such as China and India. Thus, goods with the same attributes become differentiated by their countries of origin, and are priced differently. Given this, various governments and consumer organizations of nations relying on food imports have repeatedly put forward the view that the process of further globalization should be halted. Central to the

\footnotetext{
${ }^{1}$ Other cases include unapproved toothpaste, seafood containing antibiotics, deadly pet food, etc.
} 
issue, is the popular conjecture that the global food crisis calls for more restrictions on international trade in order to increase consumption of local products. ${ }^{2}$

This paper examines the theoretical premises of such conjecture in a model of quality choices, with international trade involving tainted food and other low-quality products. We are especially interested in how an importing country can provide proper incentives such that foreign firms produce non-tainted, high-quality products. In particular, we ask questions such as: (i) Does globalization via freer trade lower product safety? (ii) How are firm profits and consumer welfare affected?

Consider two firms Home (H) and Foreign (F) competing in the Home market. The foreign firm has access to two technologies, one producing a low-quality variant (e.g., tainted food) and the other producing high quality. A domestic health authority that controls quality of imports is only able to inspect a small fraction of total shipments. This inspection ratio is determined by the home government and known to consumers before they make their consumption decisions and to firms before they make their choices of output and investment in quality. ${ }^{3}$ Given this, our setup is a sequence of moves and market structures that span over two periods. The problem of the foreign firm is to choose the optimal quality strategy by maximizing the expected net present value of profits across qualities. Of these two technologies, which one is selected is private information of the foreign firm only.

The obvious problem with imported food or other goods is that consumers are not sure about their quality. Sellers could signal quality in various ways, however, there is still no guarantee that they do not over report or even lie about quality. Thus, instead of the signaling

\footnotetext{
${ }^{2}$ In Japan, a government survey conducted in September 2008 found that 89 percent of respondents said they would choose domestically produced products over imports; 93.2 percent said that Japan should be more self-reliant in procuring foodstuffs (The Daily Yomiuri, November 16, 2008).
} 
approach that has been used in an international context, ${ }^{4}$ we adopt a different approach, namely, experience goods. The foreign firm's investment determines the quality of its product, but its quality becomes observable to consumers only through experience with the product, or by obtaining a certificate of quality issued by inspection authorities in the domestic country. This approach seems more realistic for exported goods from developing countries to rich countries, whereby experience seems more trustable than foreign promises or signaling. ${ }^{5}$

We first find that for a large class of environments, free trade is the trading system that provides the highest incentives for foreign exporters to produce non-tainted high-quality goods. In the present model of experience goods, under an import tariff, the foreign firm's profits are reduced for one period if it exports tainted goods (which cannot be sold in the second period), but for two periods if it produces high-quality goods. Under normal conditions profits are lowered more by the tariff with high-quality production than with tainted goods, which in turn reduces the foreign firm's incentives to produce high-quality goods. However, free trade is neither a necessary nor a sufficient condition to exclude trade in tainted products.

The condition for tainting not to arise is less easily satisfied if the marginal cost of high-quality production increases and low quality is always produced if this marginal cost is

\footnotetext{
${ }^{3}$ For example, it is known that the US Food and Drug Administration checks only 1\% of all shipments bound to the US market. In Japan, about 11\% of imported goods are inspected (The Japan Times Online, Nov. 26, 2008).

${ }^{4}$ For papers in signaling quality of imports, see Bagwell and Staiger (1989), Qiu (1994), Shy (2000), Daughety and

Reinganum (2008) among others. Several studies on quality restrictions and oligopoly are also closely related to the present paper, for instance, Donnefeld (1986), Krishna (1987), Das and Donnefeld (1989) and Valletti (2000).

${ }^{5}$ In the literature, Nelson (1970) was the first paper to systematically analyze the differences between experience goods and search goods, and made some predictions about consumer behavior and market structure with the two types of goods. Chen (1991) and Bergès-Sennou and Watson (2005) also adopt a setup of experience goods. In particular, Chen shows that an R\&D subsidy characterizes optimal infant industry intervention, and it can also help individual firms to more fully appropriate the benefits of quality-enhancing investment outlays. Bergès-Sennou and Watson focus on product labeling
} 
sufficiently high. Likewise this condition is also less easily satisfied if Type I and Type II errors of testing matter. The intuition can be roughly understood as follows. A Type I error harms the foreign exporter because its high-quality exports are prohibited after inspection. A Type II error is a tragedy from the domestic society's standpoint, since inspectors mistake tainted goods as high-quality ones. Obviously a Type II error benefits the foreign exporter when he produces low-cost tainted goods.

The basic setup is then enlarged to cover cases where the foreign firm invests to enhance consumers' perception of its products, i.e., image building, where we still find that free trade provides the highest incentives for high quality production. Another interesting case is sabotage by domestic competitors, which arises more often when foreign imports are of high quality. The consequence is that more tainting arises as the foreign firm's marginal cost of production is increased, which in turn allows the domestic firm to strengthen its quality leadership in high-quality production.

Our results are closely related to the stylized observation that industrialized countries generally maintain relatively high tariff and nontariff barriers in agriculture and in processed food sectors. According to the World Bank (2001), average protection in those countries was about nine times higher for agriculture than for manufacturing imports. Though tariffs have decreased in recent years, nontraditional impediments such as health, technical and sanitary standards have replaced them, and compliance to these standards imposes additional costs on exporters from developing countries. Moreover, agricultural subsidies to member countries such as those in the EU and NAFTA countries worsen the situation. The present model predicts that tainting is more severe in agriculture than in manufacturing imports; and an 
effective way of reducing tainting is to lower tariff as well as non-tariff barriers, contrary to the conventional wisdom that more import restrictions should be imposed. One obvious way to reduce tainting is to increase inspection. However, due to type I and type II errors and the high cost of inspection, this often may not be feasible. Lowering barriers is perhaps necessary when in practice governments cannot raise import inspection due to various constraints related to budget, personnel, or technology.

The paper is organized as follows. In Section 2 we lay out the setup of the model and describe the extensive form of the decision tree. Section 3 derives demand functions when consumers differentiate goods by country of origin. Section 4 derives the expected intertemporal profits of the foreign exporter under the alternatives of low- and high-quality production. We examine more closely the conditions under which tainted food is imported. Sections 5 to 7 analyze extensions of the model to include errors of testing, investments and sabotage. Section 8 deals with aggregate domestic welfare and how it relates to the model parameters. We conclude in Section 9.

\section{The Basic Setup}

Our framework consists of a domestic (H) and a foreign (F) producing firm that serve the domestic market only. The setup is a sequence of moves and market structures that span over two periods, period 1 and period 2. Panel (a) of Table 1 describes the case when firm F chooses to produce low quality. Local health authorities inspect imports with exogenous probability $\mu$. Initially we assume that authorities can always tell if a good is non-tainted after inspection. Later in Section 4 we examine errors of testing, when inspection fails to uncover tainting. Given that firm F produces low-quality goods, if its exports are inspected, 
then the shipment is not allowed to enter. If not inspected then firm F's exports are sold into the domestic market. In this case consumers cannot observe the quality of the imported good. They experience its quality instead by consuming the good in period 1 and then learn that it is of the low-quality type. With this experience they decide not to consume the low-quality good in period 2.

Table 1 Firm F's Strategies and Market Structures

(a) Firm F Producing Low Quality

\begin{tabular}{|l|l|l|}
\hline Inspection Probabilities & \multicolumn{1}{|c|}{ Period 1 } & \multicolumn{1}{|c|}{ Period 2 } \\
\hline Inspection $(\mu)$ & $\begin{array}{l}\text { No imports; domestic } \\
\text { monopoly }\end{array}$ & $\begin{array}{l}\text { No imports; domestic } \\
\text { monopoly }\end{array}$ \\
\hline No inspection $(1-\mu)$ & $\begin{array}{l}\text { Duopoly with differentiated } \\
\text { products }\end{array}$ & $\begin{array}{l}\text { No imports; domestic } \\
\text { monopoly }\end{array}$ \\
\hline
\end{tabular}

(b) Firm F Producing High Quality

\begin{tabular}{|l|l|l|}
\hline Inspection Probabilities & \multicolumn{1}{|c|}{ Period 1 } & \multicolumn{1}{|c|}{ Period 2 } \\
\hline Inspection $(\mu)$ & $\begin{array}{l}\text { Certification: duopoly with } \\
\text { homogeneous products }\end{array}$ & $\begin{array}{l}\text { Duopoly with } \\
\text { homogeneous products }\end{array}$ \\
\hline No inspection $(1-\mu)$ & $\begin{array}{l}\text { Duopoly with differentiated } \\
\text { products }\end{array}$ & $\begin{array}{l}\text { Duopoly with } \\
\text { homogeneous products }\end{array}$ \\
\hline
\end{tabular}

Panel (b) of Table 1 describes the case of firm $\mathrm{F}$ producing high quality. If the product is inspected, then the producer obtains a certificate stating that inspected products are of the highest quality, identical to that of homemade goods. In both periods 1 and 2, consumers do not need to experience the product to learn of its quality as the certificate is 
identifiable. For products that are not inspected, consumers learn of the quality through consumption and, in period 2 qualities of all goods become known. ${ }^{6}$

As Firm F has the choice between exporting high-quality or low-quality goods, its quality selection depends on the comparison of expected inter-temporal profits. Normally, higher quality goods require higher costs to produce. This, along with the market structure, will affect the firm's profits. In panel (a) firm $\mathrm{H}$ is a monopolist in all cells except when goods are not inspected in period 1. The market structure is then a duopoly with differentiated goods since consumers differentiate goods by country of origin. In panel (b), the market structure is a duopoly with homogeneous goods in all cells except when goods are not inspected in period 1. As in panel (a), the market structure is then a duopoly with differentiated goods. The next section derives consumer demands in order to compute the market equilibrium pertaining to each market structure.

\section{Consumer Demand}

A typical Home consumer consumes a numeraire good $m$, and the two differentiated goods $x$ and $x^{*}$, respectively produced by firm $\mathrm{H}$ and firm F. Goods made at Home have the highest recognition in both brand name and quality while those made in $\mathrm{F}$ have low acceptance by home consumers, due to problems of asymmetric information, brand recognition, etc. They are usually considered as low-quality goods as well, compared with those made at home. Given the above, the typical Home consumer can be assumed to maximize the following utility function:

$$
V\left(m, x, x^{*}\right)=m+U\left(x, x^{*}\right)
$$

\footnotetext{
${ }^{6}$ We abstract thus from cases where firm F may produce a mixture of low and high qualities to decrease the odds of detection. Also, with two qualities firm F may choose to produce high quality in period 1 and low quality in period 2 .
} 
where

$$
U\left(x, x^{*}\right)=x+\theta x^{*}-\left(x^{2}+x^{* 2}\right) / 2-\gamma x x^{*}
$$

where $\gamma \in(0,1]$ indicates the degree of substitutability between goods $x$ and $x^{*}$ : the two goods become more substitutable as $\gamma$ increases. ${ }^{7}$ Similar demand specifications are frequently used in the literature, see e.g. Dixit (1988) and Bester and Petrakis (1993).

Parameter $\theta \in[0,1]$ denotes the market scale for firm $\mathrm{F}$ and depends on how home consumers view the foreign made good vs. the homemade good. With $\theta<1$ the marginal utility that home consumer derives from consuming the foreign good is lower than from home goods, reflecting the argument that consumers in rich countries discount imported goods from poor countries. In practice it can represent product quality, food safety or brand recognition, etc. Note that if an imported good is found to be tainted, then $\theta=0$; and if the import passes inspection and receives a certificate, or in the second period if the good is still imported, then $\theta=1$. As for the relationship between $\gamma$ and $\theta$, we can think of the former as coming from the manufacturing process, which causes the two products to be different possibly in appearance, quality, taste, etc., but the latter as coming from consumers' perception of the products, such as from reputation, advertising, etc. ${ }^{8}$

Denote by $p$ and $p^{*}$ the price for each firm's product. Maximization of the consumer's problem in (1) subject to the standard budget constraint yields the inverse demand functions for goods $x$ and $x^{*}$ in units of good $m$ :

$$
p\left(x, x^{*}\right)=1-x-\gamma x^{*}
$$

Experience leads then to misleading results in a finite time horizon, but not in an infinite horizon.

${ }^{7}$ We do not consider the case where goods are complements, that is when $\gamma$ is negative.

${ }^{8}$ It is straightforward to show $\left|d\left(d x^{*} / d x\right) / d \gamma\right|=-\left[x^{* 2}-\theta x^{*}-\left(x^{2}-x\right)\right] / p^{2}>0$, given $\theta \in[0,1]$ such that in equilibrium $x>x^{*} \geq 0$. 


$$
p^{*}\left(x, x^{*}\right)=\theta-x^{*}-\gamma x
$$

The corresponding direct demand functions are:

$$
\begin{aligned}
& x\left(p, p^{*}\right)=\frac{1-\theta \gamma}{1-\gamma^{2}}-\frac{p}{1-\gamma^{2}}+\frac{\gamma p^{*}}{1-\gamma^{2}}, \\
& x^{*}\left(p, p^{*}\right)=\frac{\theta-\gamma}{1-\gamma^{2}}+\frac{\gamma p}{1-\gamma^{2}}-\frac{p^{*}}{1-\gamma^{2}} .
\end{aligned}
$$

Equations (3a') and (3b’) reproduce the properties known in the literature. For example, own-price effects are larger than cross-price effects. Also the market scale is higher for home goods than for foreign goods as long as $\theta<1$.

\section{Tainted Food}

Since we focus on firm F's choices and how the H government can design incentives to improve import quality, let us assume that the home firm $\mathrm{H}$ always produces high quality using a production technology represented by the cost function $C(x)=c x$, with $c<1$ to ensure positive demands. Home government levies a specific tariff $t$ on imports from F. Home health authorities charge a fixed fee $K^{*}$ to cover costs of inspection. The foreign firm has access to two technologies (indexed by $i$ ), one producing a low-quality variant $l$ and the other producing high quality $h$. Marginal costs are given by $c_{l}^{*}$ and $c_{h}^{*}$, and we require:

Assumption 1: $c_{l}^{*} \leq c_{h}^{*}$ and $c_{h}^{*}+t<c<1$.

This assumption reflects technical requirements on quality control that drive up the cost of high quality relative to that of low-quality production. The marginal cost of tainted food production is sufficiently low.

\subsection{Market Structures}


In equilibrium, different sets of prices will be charged depending on the quality choice made by firm $\mathrm{F}(i=l, h)$. As most goods we are considering are processed goods for which capacity constraints play a lesser role, we assume firms in the product market compete in price. ${ }^{9}$ Then, we can straightforwardly derive the equilibrium of the three market structures described in Table 1.

\section{Domestic Monopoly}

The domestic monopoly arises when local health authorities uncover tainted food. Likewise the situation arises when consumers experience the imported commodity as tainted. Imports are then prohibited ( $x_{l}^{*}=0$ ) and firm $\mathrm{H}$ becomes the sole supplier, as under autarky.

Given this information, domestic profits are $\pi_{l}=(1-c)^{2} / 2$ in all relevant periods and, the time profile of foreign profits becomes:

$$
\pi_{l}^{*}=-K^{*}
$$

in the first period and zero otherwise.

\section{Duopoly with Homogenous Goods}

This is the case of three cells in Table 1 (b). When domestic consumers treat foreign imports identically as home made goods, $\theta=\gamma=1$. When average costs are constant but not equal across firms, Bertrand competition yields an equilibrium in which the firm with the lowest marginal cost is the only one to produce positive output. The equilibrium price is then the limit price equal to (or slightly below) the marginal cost of the second most efficient firm:

$$
p_{h}=\max \left\{c, c_{h}^{*}+t\right\}=c
$$

\footnotetext{
${ }^{9}$ Results would not change qualitatively if Cournot competition is assumed instead but derivations would become more involving.
} 
It follows that domestic profits are driven down to zero and, foreign profits take the following values:

$$
\pi_{h}^{*}=(1-c)\left(c-c_{h}^{*}-t\right)-K^{*}
$$

in period 1 and $\pi_{h}^{*}=(1-c)\left(c-c_{h}^{*}-t\right)$ in other cells.

\section{Duopoly with Differentiated Goods}

A duopoly with differentiated goods arises in one cell of Table 1(a) and of Table 1(b), in period 1 and when imports are not inspected. Both firms make their supply decisions rationally. Each of them holds Bertrand conjecture about the decisions of the other producer. Profits of the two firms are respectively:

$$
\begin{array}{ll}
\pi\left(p_{i}, p_{i}^{*}\right)=\left(p_{i}-c\right) x\left(p_{i}, p_{i}^{*}\right), & i=l, h \\
\pi_{i}^{*}\left(p, p_{i}^{*}\right)=\left[p_{i}^{*}-\left(c_{i}^{*}+t\right)\right] x\left(p, p_{i}^{*}\right), & i=l, h
\end{array}
$$

The Nash-Bertrand equilibrium can be obtained as:

$$
\begin{aligned}
& p_{i}=\left(\frac{1}{4-\gamma^{2}}\right)\left\{\left(2-\gamma^{2}-\gamma \theta\right)+2 c+\gamma\left(c_{i}^{*}+t\right)\right\}, i=l, h, \\
& p_{i}^{*}=\left(\frac{1}{4-\gamma^{2}}\right)\left\{\theta\left(2-\gamma^{2}\right)-\gamma+\gamma c+2\left(c_{i}^{*}+t\right)\right\}, i=l, h, \\
& x_{i}=\left(\frac{1}{4-\gamma^{2}}\right)\left(\frac{1}{1-\gamma^{2}}\right)\left\{\left(2-\gamma^{2}\right)(1-c)-\gamma\left(\theta-c_{i}^{*}-t\right)\right\}, i=l, h, \\
& x_{i}^{*}=\left(\frac{1}{4-\gamma^{2}}\right)\left(\frac{1}{1-\gamma^{2}}\right)\left\{\left(2-\gamma^{2}\right)\left(\theta-c_{i}^{*}-t\right)-\gamma(1-c)\right\}, i=l, h,
\end{aligned}
$$

Using (8a) and (8b), the equilibrium profits of firm $\mathrm{H}$ are obtained as: $\pi_{1 i}=\left(1-\gamma^{2}\right) x_{i}^{2}$ for $i=$ l,h. Firm F's equilibrium profits are obtained from (8b) and (8d): 


$$
\pi_{i}^{*}=\left(1-\gamma^{2}\right) x_{i}^{* 2}, \quad i=l, h
$$

The market equilibrium obtained in (8c) and (8d) has a number of properties. For example, there exists a prohibitive tariff $\overline{t_{i}}=\left[\theta-c_{i}^{*}-\gamma(1-c) /\left(2-\gamma^{2}\right)\right]$ that shuts down imports. Also $x_{i}^{*}>x_{i}$ when $c-c_{i}^{*}-t>1-\theta$, i.e., when the difference in marginal costs is less than offset by the difference in market scales. In addition, Assumption 1 implies $x_{l}^{*} \geq x_{h}^{*}$.

The above discussion is summarized in Table 2 in terms of foreign production and foreign profits, where $\delta$ denotes the private discount factor common to all agents. For the sake of clarity we have introduced a first subscript to indicate time, and the second subscript indicates quality as before. Superscript ' $c$ ' is added to indicate when imports are checked.

\section{Table 2 The Foreign Firm's Profits}

(a) Low-quality

\begin{tabular}{|c|c|c|}
\hline Inspection Probabilities & Period 1 & Period 2 \\
\hline Inspection $\mu$ & $\left(x_{1 l}^{*}\right)^{c}=0$ & $\left(x_{2 l}^{*}\right)^{c}=0$ \\
& $\left(\pi_{1 l}^{*}\right)^{c}=-K^{*}$ & $\left(\pi_{2 l}^{*}\right)^{c}=0$ \\
\hline No inspection $(1-\mu)$ & $x_{1 l}^{*}=\left(\frac{1}{4-\gamma^{2}}\right)\left(\frac{1}{1-\gamma^{2}}\right)\left\{\left(2-\gamma^{2}\right)\left(\theta-c_{l}^{*}-t\right)-\gamma(1-c)\right\}$ & $x_{2 l}^{*}=0$ \\
& $\pi_{1 l}^{*}=\left(1-\gamma^{2}\right) x_{1 l}^{* 2}$ & $\pi_{2 l}^{*}=0$ \\
\hline
\end{tabular}

\section{(b) High-quality}




\begin{tabular}{|c|c|c|}
\hline $\begin{array}{c}\text { Inspection } \\
\text { Probabilities }\end{array}$ & Period 1 & Period 2 \\
\hline $\begin{array}{c}\text { Inspection } \\
\mu\end{array}$ & $\left(x_{1 h}^{*}\right)^{c}=1-c$ & $\left(x_{2 h}^{*}\right)^{c}=1-c$ \\
\hline No & $\left(\pi_{1 h}^{*}\right)^{c}=(1-c)\left(c-c_{h}^{*}-t\right)-K^{*}$ & $\left(\pi_{2 h}^{*}\right)^{c}=(1-c)\left(c-c_{h}^{*}-t\right)$ \\
$\begin{array}{c}\text { inspection } \\
(1-\mu)\end{array}$ & $x_{1 h}^{*}=\left(\frac{1}{4-\gamma^{2}}\right)\left(\frac{1}{1-\gamma^{2}}\right)\left\{\left(2-\gamma^{2}\right)\left(\theta-c_{h}^{*}-t\right)-\gamma(1-c)\right\}$ & $x_{2 h}^{*}=1-c$ \\
$\pi_{1 h}^{*}=\left(1-\gamma^{2}\right) x_{1 h}^{* 2}$ & $\pi_{2 h}^{*}=(1-c)\left(c-c_{h}^{*}-t\right)$ \\
\hline
\end{tabular}

\subsection{Firm F's Quality Choice}

As mentioned earlier, firm F's decisions are made at the outset of period 1, but affect profits of two periods. Then the inter-temporal profits under low-quality production are given by:

$$
\Pi_{l}^{*}=\mu\left(\pi_{11}^{*}\right)^{c}+\mu \delta\left(\pi_{2 l}^{*}\right)^{c}+(1-\mu) \pi_{1 l}^{*}+(1-\mu) \delta \pi_{2 l}^{*} .
$$

Making use of Table 2(a) yields:

$$
\Pi_{l}^{*}=-\mu K^{*}+(1-\mu)\left(1-\gamma^{2}\right) x_{1 l}^{* 2} .
$$

On the other hand, the inter-temporal profits of high-quality production are:

$$
\Pi_{h}^{*}=\mu\left(\pi_{1 h}^{*}\right)^{c}+\mu \delta\left(\pi_{2 h}^{*}\right)^{c}+(1-\mu) \pi_{1 h}^{*}+(1-\mu) \delta \pi_{2 h}^{*} .
$$

Making use of Table 2(b) gives:

$$
\Pi_{h}^{*}=(\mu+\delta)\left[(1-c)\left(c-c_{h}^{*}-t\right)\right]-\mu K^{*}+(1-\mu)\left(1-\gamma^{2}\right) x_{1 h}^{* 2}
$$

Therefore at the outset of period 1 firm $\mathrm{F}$ faces the following binary decision problem: $\operatorname{Max}\left(\Pi_{1}^{*}, \Pi_{h}^{*}\right)$; that is, choosing the optimal quality strategy by maximizing the expected net present value of profits. Using (10) and (11) we can establish the following proposition: 
Proposition 1 (Tainted food): Tainted food is produced and exported by the foreign firm when the following condition is fulfilled:

$$
\frac{(1-\mu)}{(\mu+\delta)} \frac{\left(2-\gamma^{2}\right)^{2}}{\left(4-\gamma^{2}\right)^{2}} \frac{\left(c_{h}^{*}-c_{l}^{*}\right)}{\left(1-\gamma^{2}\right)}\left\{\left(2 \theta-c_{h}^{*}-c_{l}^{*}-2 t\right)-\frac{2 \gamma(1-c)}{(2-\gamma)}\right\}>(1-c)\left(c-c_{h}^{*}-t\right)
$$

Proof: The difference in expected inter-temporal profits between low- and high-quality productions is obtained by taking the difference between (10) and (11):

$$
\Pi_{l}^{*}-\Pi_{h}^{*}=-(\mu+\delta)\left[(1-c)\left(c-c_{h}^{*}-t\right)\right]+(1-\mu)\left(1-\gamma^{2}\right)\left(x_{1 l}^{* 2}-x_{1 h}^{* 2}\right)
$$

Making use of (8d) to substitute for $x_{1 l}^{*}$ and $x_{1 h}^{*}$ :

$$
\begin{aligned}
& \Pi_{l}^{*}-\Pi_{h}^{*}=-(\mu+\delta)\left[(1-c)\left(c-c_{h}^{*}-t\right)\right] \\
& +\frac{(1-\mu)}{\left(1-\gamma^{2}\right)} \frac{\left(2-\gamma^{2}\right)^{2}}{\left(4-\gamma^{2}\right)^{2}}\left(c_{h}^{*}-c_{l}^{*}\right)\left\{\left(2 \theta-c_{h}^{*}-c_{l}^{*}-2 t\right)-\frac{2 \gamma}{(2-\gamma)}(1-c)\right\}
\end{aligned}
$$

which is positive when condition (12) is met.

Condition (12) compares the single-period profits of low-quality production with the multi-period profits of high-quality production obtained from limit pricing. It expresses the net expected profits from low-quality production in terms of all primitive parameters of the model, namely the marginal costs, parameters $\gamma, \theta, \delta, \mu$, and the import tariff $t$. For the sake of interpretation, we derive the monotonicity results of (12) in Table 3, from which we obtain:

Proposition 2: The incentives to produce tainted products are decreased if the inspection rate $\mu$, the discount rate $\delta$ or the cost of producing low-quality $c_{l}^{*}$ rises. On the other hand, 
an increase in the foreign firm's scale parameter $\theta$ or the marginal cost of home production c raises the foreign firm's incentives to produce tainted products.

Proof: see table 3 below.

Table 3 Monotonicity Results of Equation (12)

\begin{tabular}{|l|l|l|l|l|l|l|l|}
\hline & $\mu$ & $\delta$ & $c_{h}^{*}$ & $c_{l}^{*}$ & $c$ & $\theta$ & $t$ \\
\hline$\Pi_{l}^{*}-\Pi_{h}^{*}$ & - & - & $?$ & - & + & + & $?$ \\
\hline
\end{tabular}

Note that expression (12) is never met and tainted products are never produced when $c_{h}^{*}=c_{l}^{*}$. The intuition is that high-quality production is never out of reach for firms in the foreign country, simply because compliance costs that must be incurred to meet the sanitary standards imposed by the $\mathrm{H}$ government are low. These producers prefer then to make and export high-quality products. However, increasing $c_{h}^{*}$ has a non-linear effect on the profit differential but the sign cannot be determined, though it is expected to be positive.

A striking implication of this framework is the effect of the specific tariff $t$. From (13') it is immediate that:

$$
\frac{\partial\left(\Pi_{l}^{*}-\Pi_{h}^{*}\right)}{\partial t}=-\frac{\partial\left(\Pi_{h}^{*}-\Pi_{l}^{*}\right)}{\partial t}=(\mu+\delta)(1-c)-\frac{2(1-\mu)\left(2-\gamma^{2}\right)^{2}}{\left(1-\gamma^{2}\right)\left(4-\gamma^{2}\right)^{2}}\left(c_{h}^{*}-c_{l}^{*}\right) .
$$

Expression (14) can be positive or negative. An increase in $t$ causes, ceteris paribus, an increase in incentives (i.e., the profit differential) to produce tainted low-quality goods when $c_{h}^{*} \approx c_{l}^{*}$. In contrast as $c \rightarrow 1$, the partial derivative in (14) becomes negative and incentives 
to produce tainted products decrease instead. We thus have the following result, noting that freer trade in our framework means a decrease in $t$ :

Proposition 3 (Free trade): Free trade is the trading system that gives the highest incentives to foreign exporters to produce non-tainted high-quality goods when:

$$
(\mu+\delta)(1-c)>\frac{2(1-\mu)\left(2-\gamma^{2}\right)^{2}}{\left(1-\gamma^{2}\right)\left(4-\gamma^{2}\right)^{2}}\left(c_{h}^{*}-c_{l}^{*}\right) .
$$

However, free trade is neither a necessary nor a sufficient condition to exclude trade in tainted products.

This result runs counter to the popular claim put forward by some government officials and consumer organizations that unconditionally favor increased protectionism as a means to prevent tainted imports. Condition (15) is always fulfilled when $c_{h}^{*}=c_{l}^{*}$ but may fail to hold with $c_{h}^{*} \gg c_{l}^{*}$. Our results show that in fact, free trade is the trading system that provides the best incentives to trade high-quality products. However, this conclusion is undermined by local governments which in practice have introduced nontraditional impediments to trade such as health, technical and sanitary standards whose compliance imposes additional costs on exporters from developing countries.

\section{Type I and Type II Errors of Testing}

So far we have assumed that inspection is perfect so that all low-quality goods are

found and banned from entering country H. However, as plenty of evidence shows, ${ }^{10}$ errors of testing arise frequently when inspectors fail to find fault with tainted goods, and by mistake, label them as high-quality goods. We investigate this situation here. 
Table 4 Errors of Testing

\begin{tabular}{|l|c|c|}
\hline & High-quality production & Low-quality production \\
\hline Reject $\mathrm{H}_{0}$ & $\begin{array}{c}\text { Type I error }(\alpha): \\
\text { false positive }\end{array}$ & Correct \\
\hline Fail to reject $\mathrm{H}_{0}$ & Correct & $\begin{array}{c}\text { Type II error }(\beta): \\
\text { false negative }\end{array}$ \\
\hline
\end{tabular}

Let us assume that the null hypothesis $\left(\mathrm{H}_{0}\right)$ is the presumption of innocence, meaning the absence of tainting in foreign exports. Given this, Table 4 describes the two possible errors that are made in testing procedures. A Type I error $(\alpha)$ is highly undesirable from the foreign exporter's standpoint. With probability $\alpha$, the foreign high-quality good is by mistake found of being tainted. The effect of the Type I error is that his exports are denied entry into the domestic market and his reputation is tarnished. A Type II error $(\beta)$ is a tragedy from the domestic society's standpoint. With probability $\beta$, foreign tainted goods are by mistake not detected. As a consequence, a certificate of high quality is issued to the exporter but consumers' health is in jeopardy.

\section{Table 5 Testing Errors and Foreign Firm's Profits}

(a) Low-quality

\begin{tabular}{|c|c|c|}
\hline Inspection Probabilities & Period 1 & Period 2 \\
\hline Inspection $\mu(1-\beta)$ & $\left(x_{1 l}^{*}\right)^{c}=0$ & $\left(x_{2 l}^{*}\right)^{c}=0$ \\
\hline
\end{tabular}

\footnotetext{
${ }^{10}$ The New York Times (March 6, 2009) cites many examples in "Food Safety Problems Elude Private Inspectors". For instance, the American Institute of Baking which after performing audits at Peanut Corporation, reported that "the overall food safety level of this facility was considered to be superior." Federal investigators later discovered salmonella.
} 


\begin{tabular}{|c|c|c|}
\hline & $\left(\pi_{1 l}^{*}\right)^{c}=-K^{*}$ & $\left(\pi_{2 l}^{*}\right)^{c}=0$ \\
\hline Inspection $\mu \alpha$ & $\left(x_{1 h}^{*}\right)^{c}=0$ & $\left(x_{2 h}^{*}\right)^{c}=0$ \\
& $\left(\pi_{1 h}^{*}\right)^{c}=-K^{*}$ & $\left(\pi_{2 h}^{*}\right)^{c}=0$ \\
\hline
\end{tabular}

(b) High-quality

\begin{tabular}{|c|c|c|}
\hline Inspection Probabilities & Period 1 & Period 2 \\
\hline Inspection $\mu(1-\alpha)$ & $\left(x_{1 h}^{*}\right)^{c}=1-c$ & $\left(x_{2 h}^{*}\right)^{c}=1-c$ \\
& $\left(\pi_{1 h}^{*}\right)^{c}=(1-c)\left(c-c_{h}^{*}-t\right)-K^{*}$ & $\left(\pi_{2 h}^{*}\right)^{c}=(1-c)\left(c-c_{h}^{*}-t\right)$ \\
\hline Inspection $\mu \beta$ & $\left(x_{11}^{*}\right)^{c}=1-c$ & $\left(x_{21}^{*}\right)^{c}=0$ \\
& $\left(\pi_{1 l}^{*}\right)^{c}=(1-c)\left(c-c_{l}^{*}-t\right)-K^{*}$ & $\left(\pi_{2 l}^{*}\right)^{c}=0$ \\
\hline
\end{tabular}


Errors of testing affect the likelihood of different market outcomes but only occur when inspection is first performed. Table 5 reproduces part of Table 2 but corrects inspection probabilities for testing errors. The effect of Type I error $\alpha$ is that though high-quality products are made they are considered as tainted and therefore excluded from the market. As the reputation of the exporter is also ruined, we obtain new entries in panel (a) of Table 5:

$$
\left(x_{1 h}^{*}\right)^{c}=0,\left(\pi_{1 h}^{*}\right)^{c}=-K^{*},\left(x_{2 h}^{*}\right)^{c}=0,\left(\pi_{2 h}^{*}\right)^{c}=0 .
$$

The inter-temporal profits of high-quality production can be computed as:

$$
\Pi_{h}^{*}=(\mu+\delta-\mu \alpha(1+\delta))\left[(1-c)\left(c-c_{h}^{*}-t\right)\right]-\mu K^{*}+(1-\mu)\left(1-\gamma^{2}\right) x_{1 h}^{* 2} .
$$

Compared to (11) a new negative term linked to Type I error $\alpha$ enters (16). A Type I error harms the foreign exporter because its exports that were previously sold at the highquality price are now prohibited after inspection. The beneficiary of the Type I error is the domestic firm because with the same probability $\alpha$ it is a monopolist in all periods.

The effect of a Type II error is more consequential. It follows that in the first period, low-quality foreign imports are labeled as high-quality and they compete with homemade goods so we have a homogenous duopoly where the limit pricing rule applies. However, in the second period, consumers having experienced tainted imports refuse to buy them anymore. The domestic firm becomes thus a monopolist in period 2. The situation is described by the following entries in panel (b) of Table 5:

$$
\left(x_{1 l}^{*}\right)^{c}=1-c,\left(\pi_{1 l}^{*}\right)^{c}=(1-c)\left(c-c_{l}^{*}-t\right)-K^{*},\left(x_{2 l}^{*}\right)^{c}=0,\left(\pi_{2 l}^{*}\right)^{c}=0 .
$$


As indicated earlier, firm F's decisions are made at the outset of period 1, but affect profits of two periods. Repeating the steps of the preceding section, inter-temporal profits under low-quality production can be computed on the basis of Tables 2 and 5:

$$
\Pi_{l}^{*}=-\mu K^{*}+\mu \beta(1-c)\left(c-c_{l}^{*}-t\right)+(1-\mu)\left(1-\gamma^{2}\right) x_{1 l}^{* 2} .
$$

Compared to (10), a new term that is linked to the Type II error enters positively in (17): a Type II error benefits the foreign exporter when he produces low-cost tainted food because with probability $\beta$ its tainted goods are now allowed to sell at the high-quality price.

With $\alpha=\beta=0$, (16) and (17) reduce to (11) and (10) respectively. Using (16) and (17) the difference in expected inter-temporal profits between low- and high-quality productions can be written as:

$$
\begin{aligned}
& \Pi_{l}^{*}-\Pi_{h}^{*}=-(\mu+\delta-\mu \alpha(1+\delta))\left[(1-c)\left(c-c_{h}^{*}-t\right)\right]+\mu \beta\left[(1-c)\left(c-c_{l}^{*}-t\right)\right] \\
& +\frac{(1-\mu)}{\left(1-\gamma^{2}\right)} \frac{\left(2-\gamma^{2}\right)^{2}}{\left(4-\gamma^{2}\right)^{2}}\left(c_{h}^{*}-c_{l}^{*}\right)\left\{\left(2 \theta-c_{h}^{*}-c_{l}^{*}-2 t\right)-\frac{2 \gamma}{(2-\gamma)}(1-c)\right\}
\end{aligned}
$$

From (18) and the above discussion we can establish the following proposition:

Proposition 4 (Type I and Type II errors): Type I errors ( $\alpha$ ) and Type II errors ( $\beta$ ) of testing increase profits and incentives to produce and export tainted products.

It is clear from (18) that testing errors also change how the specific tariff affects the profit differential:

$$
\frac{\partial\left(\Pi_{l}^{*}-\Pi_{h}^{*}\right)}{\partial t}=(\mu+\delta-\mu \alpha(1+\delta))(1-c)-\mu \beta(1-c)-\frac{2(1-\mu)\left(2-\gamma^{2}\right)^{2}}{\left(1-\gamma^{2}\right)\left(4-\gamma^{2}\right)^{2}}\left(c_{h}^{*}-c_{l}^{*}\right)
$$


Expression (19) reduces to (14) when $\alpha=\beta=0$ but is smaller otherwise. Depending on the values of $\alpha$ and $\beta$, (19) can turn negative. Therefore, testing errors undermine the free trading system as a devise to provide incentives to produce and trade high-quality products.

\section{The Role of Investments}

So far it has been assumed that $\theta(\leq 1)$ is exogenous. However, foreign firms can undertake investments to enhance consumers' perception of their products. Their objective is to affect consumers' preference which usually favor domestically made products over imported goods, especially when they come from developing countries and when it concerns food products. Investments are done via advertising campaigns but also via trade fairs. Hence, $\theta$ becomes endogenous and an 'optimal' $\theta$ can be obtained in our model by introducing profit-maximizing investments. There are however some constraints. For example, when investing the foreign firm does not want to reveal its quality choice to consumers. Also investments are only optimal under differentiated products since in other market structures, imports are either prohibited or experienced and certified, which make investments redundant.

A duopoly with differentiated goods arises in one cell of Table 1(a) and of Table 1(b), in period 1 and when imports are not inspected. With investment the market is assumed to evolve in two stages, decisions made in the first stage being fully observable in the second stage. First, firm F decides unilaterally on how much to invest in the enhancement of the perception of its product. Second, both firms make their supply decisions rationally. Each of them holds Bertrand conjecture about the decisions of the other producer. We solve the model by backward induction. As the solution obtained in (8a)-(8b) and (9) describes the market equilibrium of the second stage it suffices to focus on the determination of investments in the first stage. 
It is important to note that the domestic firm may counteract firm F's investment in the upgrade of its market scale, by undertaking its own investment to damage firm F's product image. ${ }^{11}$ The market evolves then in two stages, with firms $\mathrm{F}$ and $\mathrm{H}$ deciding simultaneously on how much to invest. Here in order to focus on F's investment, we ignore this possibility by the following assumption:

Assumption 2: $c-c_{i}^{*}-t>1-\theta$.

Then foreign imports are larger than domestic production $\left(x_{i}^{*}>x_{i}\right)$ because the difference in marginal costs is less than offset by the difference in market scales. Also $\left(1-\gamma^{2}\right) x_{i}^{* 2}>\left(1-\gamma^{2}\right) x_{i}^{2}$, that is firm F's operational profits are larger than those of firm $\mathrm{H}$. Hence, firm $\mathrm{F}$ is able to outcompete firm $\mathrm{H}$ in an investment game if the latter decides to make investments to lower firm F's product image. As a result, firm $\mathrm{H}$ which has also other more rewarding disrupting activities (see next section) does not participate and firm $\mathrm{F}$ then becomes the sole investor.

In the second stage of the game, the profits of the two firms are respectively:

$$
\begin{aligned}
& \pi_{i}=\left(1-\gamma^{2}\right) x_{i}^{2}, \quad i=l, h \\
& \pi_{i}^{*}=\left(1-\gamma^{2}\right) x_{i}^{* 2}-f^{*}, \quad i=l, h
\end{aligned}
$$

where $f^{*}$ denotes first-stage investment which is common to both qualities and where outputs $x_{i}$ and $x_{i}^{*}$ are given by (8c) and (8d). In the first stage, firm $\mathrm{F}$ tries to improve home

\footnotetext{
11 This is one type of sabotage that we investigate later.
} 
consumers' perception of its product. In particular, it invests in order to increase its market scale variable $\theta$ by using the following linear technology:

$$
\theta=\omega+\lambda f^{*}
$$

To choose a single level of investment it is assumed that the foreign firm maximizes the sum of first-period profits $\left(\pi_{l}^{*}+\pi_{h}^{*}\right)$. Inserting (21) in $x_{i}^{*}$, the maximization of profits with respect to $f^{*}$ gives:

$$
\frac{\partial\left(\pi_{l}^{*}+\pi_{h}^{*}\right)}{\partial f^{*}}=2 \frac{\left(2-\gamma^{2}\right)}{\lambda\left(4-\gamma^{2}\right)}\left(x_{l}^{*}+x_{h}^{*}\right)-2=0
$$

Together with (8c) and (8d), this first order condition yields:

$$
\begin{aligned}
& \theta=\frac{\left(4-\gamma^{2}\right)^{2}\left(1-\gamma^{2}\right)}{2 \lambda\left(2-\gamma^{2}\right)^{2}}+\frac{\gamma(1-c)}{\left(2-\gamma^{2}\right)}+\frac{\left(c_{l}^{*}+c_{h}^{*}\right)}{2}+t, \\
& f^{*}=\frac{\theta}{\lambda}-\frac{\omega}{\lambda}
\end{aligned}
$$

The optimal level of investment is chosen such that outputs across qualities have the following properties:

$$
\begin{aligned}
& \left(x_{l}^{*}+x_{h}^{*}\right)=\frac{\left(4-\gamma^{2}\right)^{2}}{\lambda\left(2-\gamma^{2}\right)} \\
& \left(x_{l}^{*}-x_{h}^{*}\right)=\frac{\left(2-\gamma^{2}\right)}{\left(4-\gamma^{2}\right)\left(1-\gamma^{2}\right)}\left(c_{h}^{*}-c_{l}^{*}\right)
\end{aligned}
$$

Using (23a) and (23b), the difference in profits has the following simple expression:

$$
\pi_{l}^{*}-\pi_{h}^{*}=\left(1-\gamma^{2}\right) x_{l}^{* 2}-f^{*}-\left(1-\gamma^{2}\right) x_{h}^{* 2}+f^{*}=\frac{\left(c_{h}^{*}-c_{l}^{*}\right)}{\lambda}
$$

Given this information firm F's quality choice is readily obtained. Repeating the steps of Section 4 the inter-temporal profits of low-quality production can be obtained as: 


$$
\Pi_{l}^{*}=-\mu K^{*}+(1-\mu)\left(1-\gamma^{2}\right) x_{1 l}^{* 2}-(1-\mu) f_{1}^{*} .
$$

On the other hand, the inter-temporal profits of high-quality production are:

$$
\Pi_{h}^{*}=(\mu+\delta)\left[(1-c)\left(c-c_{h}^{*}-t\right)\right]-\mu K^{*}+(1-\mu)\left(1-\gamma^{2}\right) x_{1 h}^{* 2}-(1-\mu) f_{1}^{*}
$$

Making use of (24), the difference in expected inter-temporal profits between high- and lowquality productions becomes:

$$
\Pi_{l}^{*}-\Pi_{h}^{*}=-(\mu+\delta)\left[(1-c)\left(c-c_{h}^{*}-t\right)\right]+\frac{(1-\mu)}{\lambda}\left(c_{h}^{*}-c_{l}^{*}\right)
$$

Using (25) we can establish the following proposition:

Proposition 5 (Investment and tainted food): When it is optimal for the foreign firm to invest resources in image building it will produce and export tainted food when the following condition is fulfilled:

$$
\frac{(1-\mu)}{\lambda(\mu+\delta)}\left(c_{h}^{*}-c_{l}^{*}\right)>(1-c)\left(c-c_{h}^{*}-t\right)
$$

Incentives to produce low quality in (26) can be compared with those in (12). Condition (26) is satisfied when $c_{h}^{*} \gg c_{l}^{*}$. The intuition is that high-quality production is out of reach for some firms in the foreign country, due to, say, too high compliance costs that must be incurred to meet the high sanitary standards imposed by the $\mathrm{H}$ government. These producers decide then to skimp on quality and export tainted products. This is possible as long as local health authorities are only able to check a very small fraction of total shipments. 
The monotonicity results of (26) are summarized in Table 6. Note that the effect of $c$ on the profit differential is not monotone, i.e. $\partial\left(\Pi_{l}^{*}-\Pi h_{h}^{*}\right) / \partial c=-(\mu+\delta)\left(1-2 c+c_{l}^{*}+t\right)$, which is negative if $c<\left(1+c_{l}^{*}+t\right) / 2$, and positive if $c>\left(1+c_{l}^{*}+t\right) / 2$.

Table 6 Monotonicity Results of Equation (26)

\begin{tabular}{|l|l|l|l|l|l|l|l|}
\hline & $\mu$ & $\delta$ & $c_{h}^{*}$ & $c_{l}^{*}$ & $c$ & $\lambda$ & $t$ \\
\hline$\Pi_{l}^{*}-\Pi_{h}^{*}$ & - & - & + & - & $?$ & - & + \\
\hline
\end{tabular}

A striking implication of this scenario is the effect of the specific tariff $t$. From (25) it is immediate that:

$$
\frac{\partial\left(\Pi_{l}^{*}-\Pi_{h}^{*}\right)}{\partial t}=-\frac{\partial\left(\Pi_{h}^{*}-\Pi_{l}^{*}\right)}{\partial t}=(\mu+\delta)(1-c)>0 .
$$

An increase in $t$ causes, ceteris paribus, an increase in the incentives (i.e., the profit differential) to produce tainted low-quality goods. Vice versa a decrease in $t$ increases the incentives to produce non-tainted high-quality products. We thus have the following result:

Proposition 6 (Investment and free trade): When the foreign firm invest resources to improve consumers' perception of its product, free trade is the trading system that provides the highest incentives to foreign exporters to produce non-tainted high-quality goods.

This result runs counter to the popular claim put forward by some government officials and consumer organizations that favor increased protectionism as a means to prevent tainted imports. Our result shows that in fact, freer trade is perhaps necessary to induce high- 
quality non-tainted imports, when governments in practice cannot raise the rate of import inspection due to various constraints such as those on budget, personnel, or technology.

\section{Sabotage}

Foreign firm's export success is very often subject to countermeasures by the domestic firm which does not want the market for its products to fade away. Possible reactions are sabotage activities by domestic competitors. The term 'sabotage' usually refers to countermeasures in market contests that are almost unobservable and sometimes illegal. The idea stems from Veblen (1923) in the context of business competition, and market power has since been considered in several fields: for example, Baumol (1992) on innovation, Lazear (1989) on contests within firms and Konrad (2000) in the context of lobbying efforts for policy favors. Sabotage activities take at least two forms. One is damaging the rival's image, and the other is increasing the rival's costs. Since we have shown earlier that the former is dominated by improving a firm's own image, we shall focus on the latter.

Raising rival's cost is effective for firm $\mathrm{H}$, simply because some of the market equilibria of Table 1(b) might reverse in its favor. If we denote sabotage activities by $s$, marginal costs can be expressed as $c_{i}^{*}(s)$ with $\partial c_{i}^{*}(s) / \partial s>0$. The following result can be straightforwardly obtained:

Proposition 7 (Sabotage): Sabotage by the domestic firm aimed at raising the foreign firm's marginal cost of production: (i) decreases the likelihood of tainting if the marginal cost of low quality is increased; (ii) causes tainting if the marginal cost of high quality is increased. 
Proof: Sabotage of low-quality production affects only one cell of Table 2(a): when the imported good is not checked, for which consumers have to gain experience. In this case only (13) is affected. With $c_{l}^{*}(s)$ increasing in $s$, sabotage reduces both $x_{l}^{* 2}$ and the right hand side of (13). The likelihood of tainting decreases which proves part (i). To prove part (ii) note that sabotage of high-quality production affects all market equilibria of Table 2(b). With sufficient sabotage activity, the limit pricing condition (5) reverses to:

$$
p_{h}=\max \left\{c, c_{h}^{*}(s)+t\right\}=c_{h}^{*}(s)+t
$$

Foreign profits in Table 2(b) then become:

$$
\left(\pi_{1 h}^{*}\right)^{c}=-K^{*},\left(\pi_{2 h}^{*}\right)^{c}=\pi_{2 h}^{*}=0
$$

In turn, domestic profits take the following values:

$$
\left(\pi_{1 h}\right)^{c}=\left(\pi_{2 h}\right)^{c}=\pi_{2 h}=\left[1-\left(c_{h}^{*}(s)+t\right)\right]\left[c_{h}^{*}(s)+t-c\right]
$$

As a result, while (10) remains unchanged, (11) becomes:

$$
\Pi_{h}^{*}=-\mu K^{*}+(1-\mu)\left(1-\gamma^{2}\right) x_{1 h}^{* 2}
$$

The difference in expected inter-temporal profits between low- and high-quality productions is obtained by taking the difference between (10) and (11'):

$$
\Pi_{l}^{*}-\Pi_{h}^{*}=(1-\mu)\left(1-\gamma^{2}\right)\left(x_{1 l}^{* 2}-x_{1 h}^{* 2}\right)>0
$$

which is always positive. Thus tainting in this case is caused by sabotage of high-quality production by the domestic firm.

This proposition has important implications. First note that sabotage of low-quality, tainted imports only affects profits in the first period when imports are not checked whereas sabotage of high quality affects multi-period profits under all inspection status. The dominant strategy of firm $\mathrm{H}$ is therefore to affect firm $\mathrm{F}^{\text {‘s }}$ marginal cost of high quality. Firm $\mathrm{F}$ taking 
this into account will produce the low-quality variant, even worse, the incentives to produce tainted goods increase. This will allow the domestic firm to enjoy a monopoly position in period 2 as described in Table 2(a). However, home consumers have the most to lose as a consequence, since sabotage increases both foreign tainting and the home firm's market power.

\section{Welfare}

Whatever the choice of firm F, aggregate welfare of the home country is important. The $\mathrm{H}$ government can increase the probability of inspection $\mu$ by spending more resources, and/or use tariffs to maximize welfare across firm F's choices. However, the measurement of welfare is a complex issue in our context. With experience goods ex ante consumer surplus derived from consumption choices differs from unknown ex post consumer surplus because the latter includes the disutility generated by first-period consumption of eventually tainted goods. When consumption of tainted food leads to diseases or death, the disutility is so overwhelming that low-quality consumption leads to negative aggregate welfare and to the prohibition of imports in the second period. On the other hand, more often less extreme situations exist. Defective products for example do not put public health in danger and their consumption is justified if prices are sufficiently low. Also the effects of tariffs differ from the analysis thus far. While an increase in $t$ raises the marginal cost of imports in the preceding analysis, it raises the tariff revenues in a welfare analysis according to the standard prescription of trade policy in oligopolistic markets: the source of gain for the $\mathrm{H}$ government resides in the optimal capture of the foreign exporter's surplus. 
Domestic welfare is defined as the arithmetic sum of the consumer surplus $\left(C S_{i}\right)$, the home firm's profits $\left(\pi_{i}\right)$ and the tariff revenues $\left(R_{i}\right): W_{i}=C S_{i}+\pi_{i}+R_{i}$. With consumers' utility being specified in (1) and (2), we can write the consumer surplus as the net utility derived from the consumption of $x_{i}$ and $x_{i}^{*}$ :

$$
C S_{i}=\left(1-p_{i}\right) x_{i}+\left(\theta_{i}-p_{i}^{*}\right) x_{i}^{*}-\left(x_{i}^{2}+x_{i}^{* 2}\right) / 2-\gamma x_{i} x_{i}^{*}, \quad i=l, h
$$

It is clear from (28) that an increase in prices reduces the consumption of the numeraire good and therefore utility. Table 7 reproduces the above components of welfare across periods and inspection status. Its cells have been obtained using derivations of the preceding sections, and it is important to note that we use the ex ante measure of consumer surplus.

Recall that $\delta$ denotes the private discount factor common to all agents. Then the inter-temporal welfare under quality $i$ is given by:

$$
\psi_{i}=\mu\left(W_{1 i}\right)^{c}+\mu \delta\left(W_{2 i}\right)^{c}+(1-\mu) W_{1 i}+(1-\mu) \delta W_{2 i}, \quad i=l, h
$$

Making use of Table 7 yields:

$$
\begin{aligned}
& \psi_{l}=\frac{3}{8}(\mu+\delta)(1-c)^{2}+(1-\mu)\left[C S_{1 l}+\left(1-\gamma^{2}\right) x_{1 l}^{2}+t x_{1 l}^{*}\right] \\
& \psi_{h}=(\mu+\delta)\left[\frac{(1-c)^{2}}{2}+t(1-c)\right]+(1-\mu)\left[C S_{1 h}+\left(1-\gamma^{2}\right) x_{1 h}^{2}+t x_{1 h}^{*}\right]
\end{aligned}
$$

The difference between (29a) and (29b) gives the expected present value of welfare between high- and low-quality:

$$
\begin{aligned}
& \psi_{h}-\psi_{l}=(\mu+\delta)(1-c)\left[\frac{(1-c)}{8}+t\right]+ \\
& (1-\mu)\left[\left(C S_{1 h}-C S_{1 l}\right)+\left(1-\gamma^{2}\right)\left(x_{1 h}^{2}-x_{1 l}^{2}\right)+t\left(x_{1 h}^{*}-x_{1 l}^{*}\right)\right]
\end{aligned}
$$


Condition (30) expresses the net expected welfare from high-quality production in terms of marginal costs, parameters $\delta$ and $\mu$, and the specific tariff $t$. The first term is positive, with the source of the gain residing in the more competitive nature of the market for high-quality products. The contribution of the second term is unknown under general conditions because the difference in consumer surpluses cannot be signed analytically.

However, we can establish the following proposition (I'm not sure if this is important enough to be called a Prop....):

Proposition 8 (Welfare): If a higher foreign quality gives a higher first-period welfare for country $H$, then $H$ is better off (for two periods) with a higher foreign quality.

Proof: The first term of (29b) dominates that of (29a). Then whether (30) is positive or not depends on if the second term of (29b) dominates that of (29a), i.e., the first-period welfare comparison. Differentiating the second term of either (29a) or (29b) twice with respect to $c^{*}$ tells how the first-period welfare changes with $c^{*}$

$$
\frac{d \psi_{i}^{2}}{d^{2} c^{*}}=\frac{1}{(2-\lambda)\left(1-\gamma^{2}\right)\left(2+\gamma^{2}\right)}>0 .
$$

That is, $\psi_{i}$ is convex in $c^{*}$. If a higher foreign quality gives a higher first-period welfare for country $\mathrm{H}$, then the foreign firm must be producing where $\psi_{i}$ is rising in $c^{*}$.

NON-Uniform Tariff: tariff in $1^{\text {st }}$ period only?? Welfare might be higher than free trade?

\section{$\{\{I$ think this would be very interesting and possible in practice. $\}\}$}




\section{Table 7 Components of Domestic Welfare}

\section{(a) Firm F Produces Low Quality}

\begin{tabular}{|l|l|l|}
\hline $\begin{array}{l}\text { Inspection } \\
\text { probabilities }\end{array}$ & Period 1 & Period 2 \\
\hline Inspection $\mu$ & $\left(C S_{1 l}\right)^{c}=(1-c)^{2} / 8$ & $\left(C S_{2 l}\right)^{c}=(1-c)^{2} / 8$ \\
& $\left(\pi_{1 l}\right)^{c}=(1-c)^{2} / 4$ & $\left(\pi_{2 l}\right)^{c}=(1-c)^{2} / 4$ \\
& $\left(R_{1 l}\right)^{c}=0$ & $\left(R_{2 l}\right)^{c}=0$ \\
\hline No inspection & $C S_{1 l}=\left(1-p_{1 l}\right) x_{1 l}+\left(\theta-p_{1 l}^{*}\right) x_{1 l}^{*}-\left(x_{1 l}^{2}+x_{1 l}^{* 2}\right) / 2-\gamma x_{1 l} x_{1 l}^{*}$ & $C S_{2 l}=(1-c)^{2} / 8$ \\
$(1-\mu)$ & $\pi_{1 l}=\left(1-\gamma^{2}\right) x_{1 l}^{2}$ & $\pi_{2 l}=(1-c)^{2} / 4$ \\
& $R_{1 l}=t x_{1 l}^{*}$ & $R_{2 l}=0$ \\
\hline
\end{tabular}

(b) Firm F Produces High Quality

\begin{tabular}{|l|l|l|}
\hline $\begin{array}{l}\text { Inspection } \\
\text { probabilities }\end{array}$ & Period 1 & Period 2 \\
\hline Inspection $\mu$ & $\left(C S_{1 h}\right)^{c}=(1-c)^{2} / 2$ & $\left(C S_{2 h}\right)^{c}=(1-c)^{2} / 2$ \\
& $\left(\pi_{1 h}\right)^{c}=0$ & $\left(\pi_{2 h}\right)^{c}=0$ \\
& $\left(R_{1 l}\right)^{c}=t(1-c)$ & $\left(R_{2 h}\right)^{c}=t(1-c)$ \\
No & $C S_{1 h}=\left(1-p_{1 h}\right) x_{1 h}+\left(\theta-p_{1 h}^{*}\right) x_{1 h}^{*}-\left(x_{1 h}^{2}+x_{1 h}^{* 2}\right) / 2-\gamma x_{1 h} x_{1 h}^{*}$ & $C S_{2 h}=(1-c)^{2} / 2$ \\
$(1-\mu)$ & $\pi_{1 h}=\left(1-\gamma^{2}\right) x_{1 h}^{2}$ & $\pi_{2 h}=0$ \\
& $R_{1 h}=t x_{1 h}^{*}$ & $R_{2 h}=t(1-c)$ \\
\hline
\end{tabular}




\section{Concluding Remarks}

This paper considered international trade in tainted food and examined various designs of incentive schemes such that exporting firms produce non-tainted, high-quality products. The issue arises because various governments and consumer organizations relying on food imports have repeatedly put forward the view that the process of further globalization should be halted. Central to the issue, is the popular conjecture that the global food crisis calls for more restrictions on international trade in order to prevent imports of tainted food. However, a main result of this paper shows the opposite: for a large class of environments, free trade is the trading system that provides the highest incentives to foreign exporters to produce non-tainted high-quality goods.

The setup of this paper could be extended in a number of ways. For example, so far we have assumed that a good is not imported once inspected by authorities. It is possible to allow imports of such goods as long as they are not poisonous, and label goods as 'low quality' by authorities. The model becomes then a model with two different types of qualities (but no tainting). The assumption of certification could also be relaxed. With certification, there is no reason for consumers to discount imports. Authorities certify that foreign goods are of the same grade as home goods. This was the scenario envisaged in Table 1(b). However, an inefficient firm $\mathrm{H}$ has incentives to lobby the government against the act of certification simply because in its absence, consumers keep on discounting foreign goods and product differentiation is maintained. Most qualitative results of the paper are not altered in this new setting. Finally, many industrial countries rely on imports for most of the food they 
consume. ${ }^{12}$ Hence, relying on a single home producer as indicated in Table 1 might not be feasible once tainted food is uncovered (by inspection or by experience), simply because the home monopolist does not produce enough in calorie terms. Finding a substitute for firm $\mathrm{F}$ is possible if the model considers more foreign firms. This would not change results as long as Assumption 1 is maintained, i.e., as long as the firm with the lowest marginal cost is an exporting firm. Bertrand competition then yields market equilibria that are similar to those described in the paper. Though domestic welfare will differ, incentives to the foreign firm are not altered, and most propositions still remain robust. Finally, the H-government could impose tariffs on first-period imports only, and let imports come in free in the second period. This then rewards high quality exporting in the second period and home welfare might be improved.

\footnotetext{
${ }^{12}$ For example, Japan's food self-sufficiency rate stood at 39 percent in 2006, the lowest level in industrialized countries. Rice, eggs and a few other types of food are the only food items the country currently produces sufficiently to meet domestic demand (The Daily Yomiuri, November 4, 2008).
} 


\section{References}

Bagwell, K. and Staiger, R. W. (1989), 'The role of export subsidies when product quality is unknown,’ Journal of International-Economics 27(1-2), 69-89.

Baumol, W.J. (1992), 'Innovation and strategic sabotage as a feedback process,' Japan and the World Economy 4, 275-290.

Bergès-Sennou, F. and Waterson, M. (2005), 'Private label products as experience goods,' Journal of Agricultural \& Food Industrial Organization 3(2), 1121-1121.

Bester, H. and Petrakis, E. (1993), 'The incentives for cost reduction in a differentiated industry,' International Journal of Industrial Organization 11, 519-543.

Chen, M.L. (1991), 'The role of R\&D subsidies when incomplete information is an entry-barrier,' Journal of International Economics 31(3-4), 251-270.

Daughety A.F. and Reinganum, J.F. (2008), 'Communicating quality: a unified model of disclosure and signaling,' RAND Journal of Economics 39(4), 973-989.

Dixit, A. (1988), 'Optimal trade and industrial policies for the US automobile industry,' in Feenstra, R. (ed.), Empirical Methods for International Trade Policy (Cambridge, Mass.: MIT Press), 161-185.

Donnenfeld, S. (1986), 'Intra-industry trade and imperfect information about product quality,' European Economic Review 30(2), 401-417.

Das, S. P. and Donnenfeld, S. (1989), 'Oligopolistic competition and international trade: quantity and quality restrictions,' Journal of International Economics 27, 299-318.

Konrad, K.A. (2000), 'Sabotage in rent-seeking contests,' Journal of Law, Economics and Organization 16(1), 155-165.

Krishna, K. (1987), ‘Quotas with endogenous quality,' Journal of International Economics 23, 97122.

Lazear, E. (1989), 'Pay equality and industrial policy,' Journal of Political Economy 97, 561-580.

Nelson, P. (1970), 'Information and consumer behavior,' Journal of Political Economy 78(2), 311329.

Qiu, L. (1994), 'Optimal strategic trade policy under asymmetric information,' Journal of International Economics 36, 333-354.

Shy, O. (2000), 'Exporting as a signal for product quality,' Economica 67(265): 79-90. 
Valletti,T.M. (2000),'Minimum quality standards under Cournot competition', Journal of Regulatory Economics 18, 237 - 247.

Veblen, T. (1923), Absentee Ownership and Business Enterprise in Recent Times (New York, NY: B.W. Huebsch).

World Bank (2001), Market Access for Developing Countries’ Exports (Washington, D.C.: World Bank) 